\title{
我国の維持管理の展開とその特徵 一橋梁を中心として一
}

\author{
阿部 雅人 $1 \cdot$ 阿部 允 $^{2} \cdot$ 藤野 陽三 3 \\ 1正会員 株式会社BMC 主幹研究員（†261-7125千葉市美浜区中瀬2-6 WBGマリブウェスト25階） \\ E-mail:masato@hashimori.jp \\ 2フェロー 株式会社BMC 代表取締役（同上） \\ E-mail:abem@hashimori.jp \\ 3フェロー 東京大学大学院教授 工学系研究科社会基盤学専攻（†113-8656東京都文京区本郷7-3-1） \\ E-mail:fujino@civil.t.u-tokyo.ac.jp
}

社会基盤ストックの老朽化を背景として，維持管理に関わる学術や実務の取り組みが強化されている. 維持管理は総合的な学術領域に属し, その対象とする技術分野や問題は多岐にわたる. 本研究は, 俯瞰的 な視点から，我国の社会基盤の維持管理の特徵と課題を明らかにすることを目指すものである. 橋梁を中 心として我国の発展の歴史を振り返るとともに, 米国での取り組みとの比較を通して, 考察を進める. 歴 史的には，それぞれの時代に顕在化した陳腐化・劣化・初期不良を背景として維持管理が進展して来た経 緯を明らかとし, 米国との比較から, 我国では維持管理の社会的側面より技術的側面が重視されてきた傾 向にあること，また，日米ともに，系統的な検査の実施と情報の管理が，技術の発展に大きな影響を与え ていることを論じる。

Key Words : maintenance engineering, stock management, bridges, history of technology, international comparison

\section{1. はじめに}

社会基盤ストックの老朽化を背景として, 維持管理に 関わる学術や実務の取り組みが強化されている ${ }^{1)}$. 維持 管理は総合的な学術領域に属し，その対象と寸る技術分 野や問題は多岐にわたる. そのため, 個別対象別のノウ 八ウ的な蓄積として技術が存在しており，その全体像の 把握は容易ではない.

そこで, 我国の社会基盤の維持管理のこれまでの発展 を整理し，その特徴を明らかとすることを目的として検 討を行った. 具体的には, 我国の技術発展の歴史を振り 返るとともに，米国での取り組みとの比較を通して，一 つの俯㒈的な視点を与え，今後のあるべき姿について考 察を加えるという方法で議論を進める．見通しよく議論 を進めるために, 取り上げる事例は特徽的なものに限る こととして，網羅的な整理や詳細に関する記述，個別の 問題に関する評価等については取り扱わないこととし, 参考文献（例えば文献2)-5)）に譲ることとした. したが って, 多くの重要な事例や問題を割愛せざるを得なかっ たことに留意されたい，また，社会基盤構造物の中でも，
経年が長く, 戦前期を含めて既往の維持管理に関する記 録が豊富な鋼橋を中心とした記述となっている.

なお，2章，3章で歴史的経緯を踏まえて日米の現況に ついてレビューし, 次いで, 4章でそれらの比較考察を 行う.

\section{2. 我国における維持管理の発展}

ここでは，我国における社会基盤の維持管理の歴史を 橋梁を中心として振り返り, 現在の維持管理工学の位置 について論じる，我国の橋梁技術は，歴史上，鉄道整備 を端緒として，その技術および技術者が道路に波及をし ていった経緯があるのことから，本報告では，道路橋・ 鉄道橋とも橋梁技術として一連のものとして捉え，俯瞰 的な議論を試みている．特に，戦前期には鉄道整備が社 会基盤整備の主体であったことから，構造物の経年が長 く, 維持管理の歴史も長い鉄道橋に関する記述に重点を おいて議論を進める. 


\section{(1) 明治期}

我国の近代土木工学は明治維新に始まる. 鉄道橋に目 を向けると》，当初は外国人技術者による設計・施工指 導と人材育成が行われており，先進国の技術体系を導入 したため, それまでに先進国において経験されている事 故の経験も暗黙裡に導入されたと考えられる。例えば, 交番応力の影響を考慮する形で, 疲労にも一定の配慮が なされていた. また，維持管理の容易さへの配慮も見ら れ，ポーナル設計による作錬式錬鉄桁（明治 18 年 : 1885 年) では, 再利用を想定して上下フランジの設計 が全く同一であった．類似の例として，上下フランジと も走行に利用できる踏面形状となっていた双頭レールが ある. なお，鋼鉄道橋は，これ以降も標準設計で整備さ れることが多かったが，それにより，損傷などの問題が 発生した場合の効率的な対処が可能となって, 維持管理 上極めて有利であった.

その後, 日本人による標準設計が行われるようになっ た. 明治 42 年（1909 年）の達 680 号標準桁では, 鋼材 使用量を減らすため, 下フランジプレートの長さを力学 的に必要な長さに短縮しているが，そのことによって支 点部分にき裂が発生するなどの不具合が発生したことが 指摘されている3. 力学的な材料最適化の重視によって 維持管理上の不具合を招いた例はこの後も多いが2)，そ の最初の例の一つであると思われる. 力学的な検討は理 論を学べば可能であるが，維持管理に関わる洞察は経験 がないと難しい面があることを示していると考えられる。

この時代の橋桁は, ベースプレートを介して下部構造 に面的に支持されていたが，桁端部の損傷の経験から， 大正 8 年（1919年）の達 540 号以降は独立した支承構造 が設けられるようになった。 このように，外国の技術を 取り入れる一方, 工夫を加え, 失敗も経験しながら技術 を進展させていったことがわかる.

また，大正 4 年（1915 年）の土木学会誌創刊第 2 号に は，枕木の寿命算定 9 や，軌道の経済的取替周期(1) に関 するドイツ語文献の抄訳が掲載されており，当時，既に， 維持管理全般に高い関心が寄せられていたことが伺える。

鉄道以外の分野における明治時代の重要な取り組みと して，小樽港築港工事における廣井勇によるコンクリー 卜の供試体約 6 万個による長期耐久性試験の実施が挙げ られる ${ }^{11)}$. その供試体は，現在も定期的に試験が行われ， 100 年以上にわたる貴重なデータを提供している. この ように，外国技術の導入期においても，長期にわたるデ 一夕収集の重要性が既に認識されており, 独自の耐久性 への取り組みがなされていたことは注目に值する.

\section{(2) 大正から戦前にかけて}

大正期には，明治期に整備された鉄道幹線において, 機関車の大型化ならびに高速化によって荷重が増加した
ため, 既存の橋梁の耐荷力が不足し, 陳腐化が進んだ. なお，本報告では，「陳腐化」は，物理的に性能が低下 する「劣化」と対を成す概念として，経済学でいう陳腐 化 (obsolescence) ${ }^{12)}$ に相当する意味で用いることとして, 社会・経済的条件の変化によって, 時を経るにつれて機 能が不十分となる過程を指すものとした.

これらの耐荷力が不足する橋梁は, 弱小桁と呼ばれ, 取替や補強対策の対象となった. 維持管理上注目す心゙き 点として, 架け替えられた旧桁は, 必ずしも廃棄される のではなく転用・再利用されたことと, 補強と取替の選 択においてライフサイクルコスト (life cycle cost: LCC) を考慮した経済的検討がなされていることが挙げられる. 転用では，旧桁の耐荷力を向上させる改造をした上で, 新線等に用いられた. そのため, 特に, 交通量が大きく ない地方鉄道線や歩道橋, 道路として, 明治時代の橋桁 がこの時期の改造を経て数多く現存している51,13).

この時期の代表的な補強工法は，一種の外ケーブル設 置工法であるフィンク補強であった. 曲げ耐力の向上を 図ったものであって，桁下空頭が十分にある場合に盛ん に用いられた，文献 14)では，実際の工事費の比較を行 い, フィンク補強の経費が新設の 3 分の 1 程度であるこ とから，5\%の金利を前提として，8年間で償却するとい う議論を行っている. それに対して，この工法が十数年 程度の耐久性があるとして, 有効性を示している. これ は，初歩的な LCC 分析であったと理解できる.

この補強法は, 原理的に, 曲げ耐力の夕に着目した補 強法であることから, 水平方向の剛性やせん断耐力が相 対的に不足して, 補強が実施された橋には振動やき裂な どの問題がみられるようになり, 戦後, 順次取り替えら れた. ただし，そもそも十数年程度の延命を意図したも のであるから，本来の目的は達成していると考えられる． その後, 溶接技術が進歩したことから, 鋼材を既存桁 に溶接して断面を増強する溶接補強が主流となる．溶接 補強は鋼材使用量が抑えられることも大きなメリットと された. 溶接補強についても, 簡単な経済的分析がなさ れており, 耐用年数が 20 年から 30 年と, 新桁の耐用年 数（40 年から 60 年と想定）のほぼ半分であることから, 取替の 40 パーセント以内の経費で実施可能な場合は, 溶接補強を採択寸るという基準で実施されていた ${ }^{15}$.

このように，当時，既に，経済性を含めた総合的技術 として維持管理が捉えられていたことが伺える. なお, 長大橋でも転用や補強が行われており ${ }^{10}$ ，大規模なもの としては，大正14年（1925年）に，関西本線木津川橋梁 においてポニートラスを補剛してランガー型式に改造し た例がある、これらの対策は，鋼材が貴重であった当時 の社会情勢を背景にしているが，現代的な観点からは， 廃棄物や環境負荷の問題に示唆を与える取り組みである とも言えよう。 


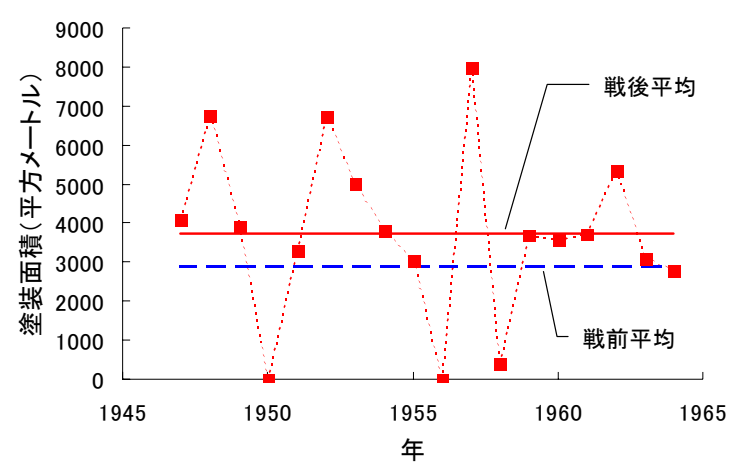

(a) 塗装

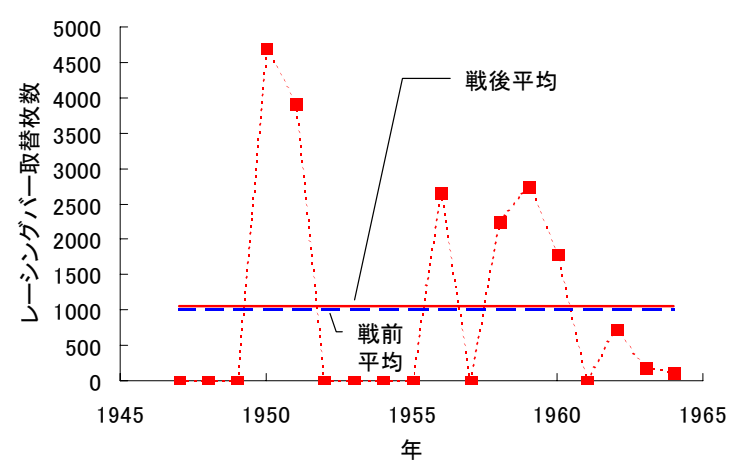

(b) レーシングバー取替

図-1 餘部橋梁の戦前戦後の維持管理

（文献19)より作成. 戦後は1947-1964年, 戦前は1941年以前の平均值.）

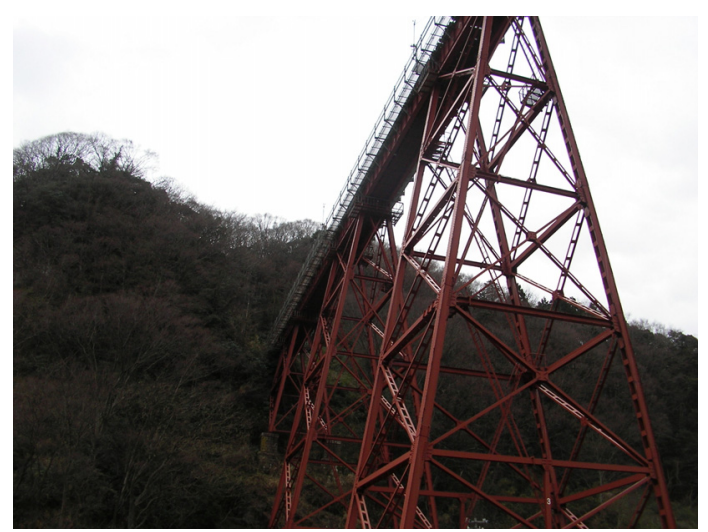

写真-1 餘部橋梁の橋脚

\section{(3) 戦中 · 戦後期}

戦中・戦後期においては，輸送需要の急増と資材不足 を背景に，維持管理不足による荒廃が進んだ。

戦争末期の昭和19年（1944年）12月20日には，室蘭線 鷲別地下道架道橋において，機関車が走行中に主桁が破 断するという事故が発生している ${ }^{17,18)}$. 㛜しい腐食環境 にある餘部橋梁（写真-1）では，戦前に行われていた塗 装と腐食レーシングバーの取替による維持管理が，戦争 末期から終戦直後にかけて4年間ほど中断したため，腐 食が進んだ. 図-1に，戦後の維持管理数量と戦前・戦後 の平均值を示す．塗装のペースは戦前に比べて $30 \%$ 程度 増加している.レーシングバーは, 戦後, 腐食しにくい タイプレートへの取替えが進められたものの，取替のペ 一スは戦前と同程度のままである. したがって, 戦後, 必要な維持管理の水準は上昇していると考えられ, 戦中 に放置されたことによる荒廃の影響が示唆される.

終戦後には，国鉄全線の調査が行われている，その結 果，全鉄林の $15 \%$ にある約 10 万トンの耐荷力が当時 走行機関車荷重以下であることが明らかとなり ${ }^{20)}$, 計画 表-1＼cjkstart鉄桁の保守方法と管理費との関係 ${ }^{15)}$ （1955 年当時）

\begin{tabular}{|c|c|c|c|c|c|}
\hline \multirow{2}{*}{$\begin{array}{c}\text { 塗装周 } \\
\text { 期 }\end{array}$} & \multirow{2}{*}{$\begin{array}{l}\text { 推定耐 } \\
\text { 用年数 }\end{array}$} & \multicolumn{3}{|c|}{ 毎年鉄桁 1t 当り } & \multirow{2}{*}{$\begin{array}{l}\text { 全鉄桁 } 60 \\
\text { 万 } \mathrm{t} \text { 対 } \\
\text { する全管 } \\
\text { 理費 } I+M\end{array}$} \\
\hline & & $\begin{array}{c}\text { 取替償却 } \\
\text { 費 } I\end{array}$ & $\begin{array}{l}\text { 塗装保 } \\
\text { 守費 } M\end{array}$ & $\begin{array}{l}\text { 国鉄管 } \\
\text { 理費総 } \\
\text { 額 } I+M\end{array}$ & \\
\hline 無保守 & 25 年 & 4,200円 & 0円 & 4,200 円 & 25.1億円 \\
\hline 8 年 & 45年 & 2,340円 & 375 円 & 2,715 円 & 16.4億円 \\
\hline 5年 & 70 年 & 1,500 円 & 600 円 & 2,100 円 & 12.6億円 \\
\hline 2年 & 100 年 & 1,050円 & 1,500 円 & 2,550 円 & 15.3 億円 \\
\hline 1 年 & 200年 & 525 円 & 3,000 円 & 3,525 円 & 21.3 億円 \\
\hline
\end{tabular}

的な取替・補強が進められた．また，塗装不足による劣 化も大きかったことから，塗装の最適周期について， 表-1 のように，国鉄鉄桁 60 万トンに対する概算の検討 が行われている. 8 年に 1 回の塗り替えで橋桁本体の耐 用年数が 45 年程度となるという実績に基づいた算定を 行って, 45 年という值を得ている. この值自体は, 当 時の塗装・ケレン技術や列車からの污物など，現在とは 異なる劣化状態が前提であって，今では意味をもたない が，保有する全橋梁の経費の最小化を意図している点で, 一種のストックマネジメントの試みであったと考えられ る. さらに, 橋梁が強度不足である場合の速度制限や, 災害・工事による徐行を対象として, 運転経費や時間の 損失などの間接費用の評価が行われており，アセットマ ネジメント的な取り組みもなされていた.

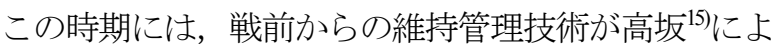
り整理されるなど，効率化を念頭においた実務的な技術 の体系化の動きが進められている．また，国鉄建造物保 守心得（案） ${ }^{21}$ が策定され，検查や台帳情報管理のシス テム化も進められている. 


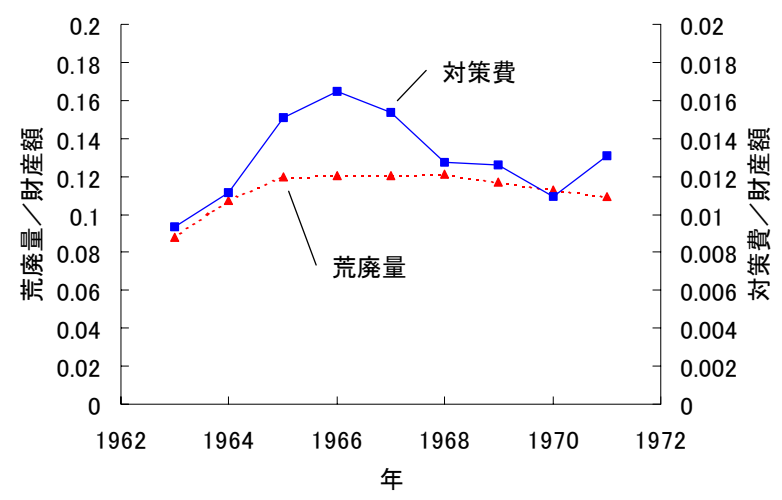

図-2 旧国鉄における対策費と荒廃量の推移

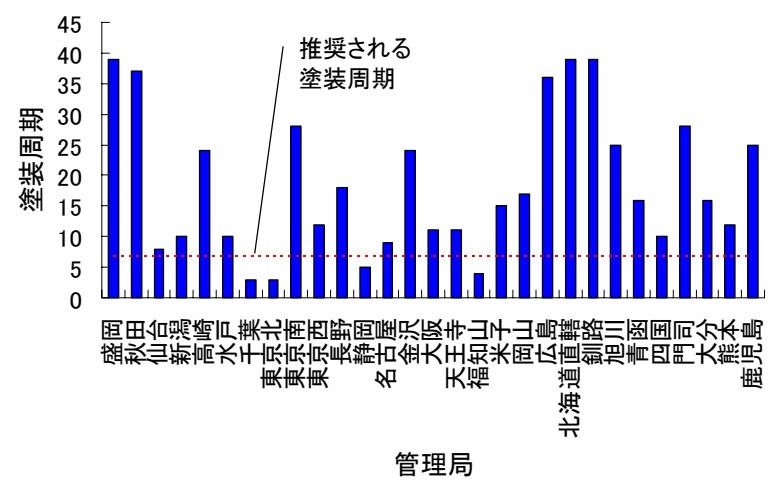

図-4 旧国鉄における推計塗装周期

これらの取り組みによって, 系統的に構造物の検查結 果が得られるようになり，技術的知見の蓄積や統一的な 基盤での集計が可能となったことは，その後の維持管理 技術の発展上，大きな意義を持つものであった.

この時代は, 戦中の放置による劣化の進行を背景とし て, 維持管理の重要性や, ストックとして管理すること の必要性が認識され, 系統的な取り組みが始められた時 期であったと言える.

\section{(4) 高度成長期およびそれ以降}

高度経済成長期には，新幹線や高速道路に代表される 大量の社会基盤の整備が行われ，設計・施工技術も大き く発展する.この時期に建設された膨大なストックの維 持管理・マネジメントが現在の大きな課題となっている この時代には，耐久性設計・施工の考え方も確立されて おらず，現在の基準で考えれば，必ずしも耐久性上優れ た品質でないものも多く含まれている可能性が高い222 とも，問題をより困難としている.

大量整備に伴って, 鋼構造では溶接構造が広範囲に採 用され, 新幹線では鋼橋の疲労損傷が顕在化している. また，道路橋においても $\mathrm{RC}$ 床版の疲労問題が発生して 合成桁構造が用いられなくなるなどの耐久性に関する問

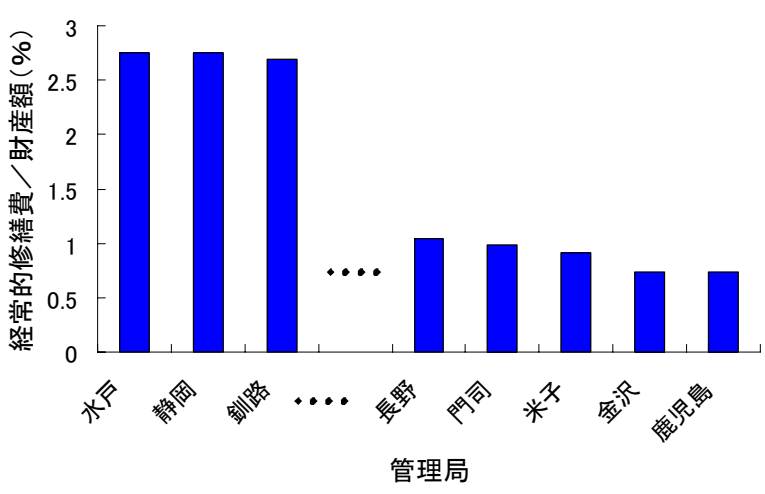

図-3 旧国鉄における管理局別維持管理費水準

題が発生している．これらの損傷は，溶接構造や合成析 構造などの，合理化を目指した新しい構造技術の本格的 導入に伴って発生した，初期欠陥的な不具合であると考 えられる.

このような背景を受けて，道路分野においても維持管 理への関心が高まり, 道路維持修繥要綱 23)や道路橋補修 便覧 ${ }^{24}$ が刊行され，維持管理工法の標準化が進められた. さらに, 道路橋点検要領（案）29が提案されるなど，検 查・診断の標準化が進んだ. また，大型車に対する活荷 重規定の改定に対応して, 既存構造物の而荷力不足が生 じ，補強が行われるようになる20. 荷重の増大に対して， 構造物の対策が求められているという点では, 大正期の 鉄道と類似の情勢であると考えられる.

鉄道分野では，建造物保守心得（案）によって，構 造物の情報が一定の水準で集まるようになったが，よ り定量的かつ客観的な情報を得ることを目的として, 建造物検查標準解説27がまとめられるなど, 検査の質を 高める努力も進められた. さらに, こうして蓄積され た情報に基づいて, 検查に留まらず, 変状の原因の究 明や健全度の判定, そして対策措置までを対象とした 「土木構造物取替の考え方」 ${ }^{28}$ がまとめられ, その後 の維持管理の体系的基盤を与えるものとなった，なお， 定期的な保守が求められる鉄道軌道については, 取替 を前提とした最適構造の研究が行なわれており, 東海 道新幹線の軌道構造設計に反映されている299.

また，構造物検査データの蓄積を背景に，防災投資の あり方についても，具体的な検討がなされるようになっ てきた．例えば，文献 30)では，図-2 のように，今後 5 年以内に取替または修䋨の必要があると認められた建造 物の取替・修繥費を荒廃量として集計してその推移を示 している. また, その結果に基づいて, 荒廃量を低減す るためには更なる対策費用が必要であることを主張する とともに，図-3,4 のような各鉄道管理局の保全費用の 比較から，適正な経費投入水準のあり方に関する議論を 行っている. 


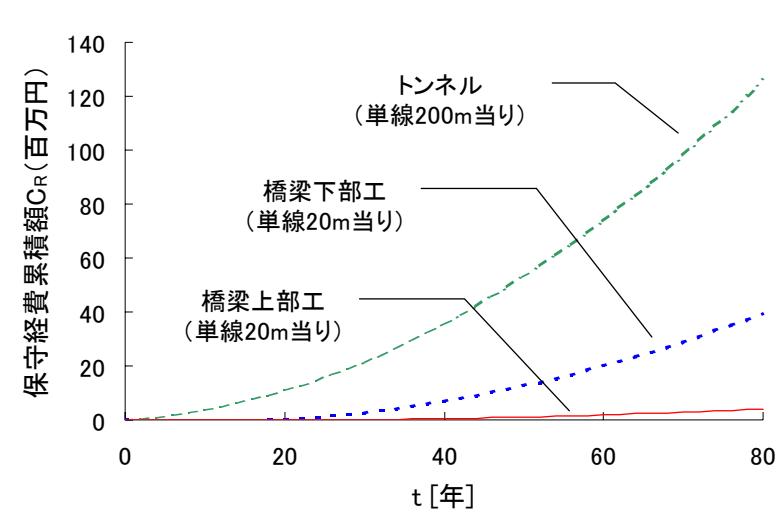

図-5＼cjkstart構造物の経年と保守経費累積額 (文献 33)より作成)

1980 年代に入ると, 「建造物保守管理の標準・同解 説」31),32)が刊行され，基準類の現代化が進められた。同 じ時期に，補修費用を考慮した最適取替時期の試算が行 われている33). 旧国鉄での 80 年間の保守，大規模修繥 累積投資額のデータに基づいて，1980 年の貨幣価值に 換算した回帰式を求め，実績から得られなかった 81 年 目以降の修繥投資額の予測を行い，統計的に検討したも のである，そこで得られた累積維持管理費用曲線を図-5 に示す。こうして得られた維持管理費用と, 別途算定し た平均取替投資額の和を最小化することによって，最適 取替時期が計算されている. その結果，橋梁上部工およ びトンネルについては 110 年，橋梁下部工については 60 年という值が得られている. 実績に基づく LCC最小化 の試みと言えよう。

図-5では，累積維持管理費用曲線が2次曲線で与えら れている。言い換えれば，経年に対して，年平均補修費 用が線形に増加していることになる．それを経験的事実 として仮定すると，時間を $t$, 累積補修費用を $C_{R}$ とすれ ば， $c_{m}$ を定数として，

$$
C_{R}=c_{m} t^{2}
$$

と表すことができる，さらに，初期費用を $C_{I}$ とすれば, 年あたり平均費用 $c$ は, 相加・相乗平均の関係から,

$$
c=\frac{C_{I}+C_{R}}{t} \geq 2 \sqrt{C_{I} c_{m}}
$$

となり，平均費用を最小化する最適寿命は，

$$
t_{\text {opt }}=\sqrt{\frac{C_{I}}{c_{m}}}
$$

で与えられる，そのときの累積補修費用は

$$
C_{R}\left(t_{\text {opt }}\right)=c_{m} t_{\text {opt }}^{2}=C_{I}
$$

となる，すなわち，「累積補修費用が初期費用と同等に なったときが取替時」といら経験則が得られる.

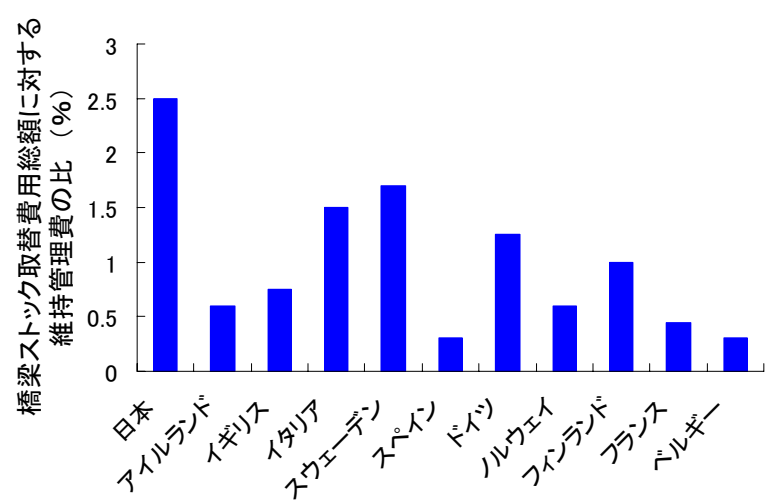

図-6＼cjkstart維持管理費水準の国際比較 (文献 34)より作成)

この結果に基づいて，例えば，次のような検討を行う ことができよう。ある管理主体で，ストックの総再取得 価格の $1 \%$ 年あたりの維持管理費用であるとする. そ の主体におけるストックの経年分布が一様であるならば, 100 年程度の平均寿命が暗黙に想定されていると推論す ることができる. なお，この維持管理水準の值は，図-6 に挙げた国際的な水準とも整合的である.このように統 計が整備されていれば，観察された統計的現象に基づい た推論が可能となる.したがって，当時は，劣化予測な どの技術は未発達であったと考えられるものの, 検査デ 一夕に基づいて一定の合理性をもった維持管理を実施す る基盤が成立していたと考えられる。

この時代には，高度成長期における従来にない水準の 社会基盤の大量整備に伴って発生した初期不良的な不具 合を背景として維持管理技術が進展するとともに, 維持 管理技術の基準化が開始されている．また，主として鉄 道分野において，それまでに蓄積された維持管理に関す る情報から得られた知見が，技術へフィードバックされ るようになったことも重要な進展である.

\section{(5) 現代}

それまでの維持管理技術への取り組みは，実際のニー ズに基づいた実務的な発展が中心であったが，1980 年 代後半から, 学協会での取り組みや学術的な体系化の動 きが本格化している. 例えば，日本鋼構造協会において は，「鋼構造物の疲労設計指針・同解説」35)が作成され ており，土木学会では「コンクリート構造物の耐久性設 計指針」 ${ }^{39}$ 「「ンクリート構造物の維持管理指針」37な どの作成が進み，コンクリート標準示方書［維持管理 編] ${ }^{38}$ につながっている. また, 個別の学術的研究の進 展もみられた. 一例として, 道路橋RC床版の疲労メカ ニズムが研究され, 耐久性の評価が可能となったことが 挙げられる39)。さらに，それにより，耐久性を考慮した 新しい合成桁構造が提案されるようになり ${ }^{40}$, 橋梁工学 
における重要なブレークスルーとなった.このように, 維持管理においても，ニーズに基づく学術的な取り組み が推進され，また，そこで得られた学術的成果が実務に フィードバックされるという循環が起こっていることが わかる. この段階において，学術的な意味での維持管理 の位置付けが確立したと考えられる.

1995 年の兵庫県南部地震は, 土木工学に極めて大き な影響を与えたが，維持管理に関連した課題に限れば, 地震被害を受けて，既存ストックの耐震補強が大規模に 行われたことが挙げられよう。そのことによって，スト ックとして社会資本を捉えることの重要さが明確に示さ れ, また, 既存ストックの安全性のあり方に対する問題 提起となっていたと言える. その後, コンクリート剥落, 鋼橋脚の疲労き裂発生など, 維持管理に関連する社会的 な影響の大きい問題が頻発するようになった。これら問 題が発生した構造物は，高度経済成長期のストックであ り，品質の問題 ${ }^{22}$ が顕在化した事例も見られ，社会的に も関心が高まった。

その後, 大学での講義 ${ }^{41)}$ や学協会での資格講習42),43)な どがスタートし，これまでの，どちらかと言えば実務や 研究主体の学術から, 教育や人材育成を含めた学術的な 体系化が進められている，資格においては，従来からあ る非破壊検査のような個別技術・技能の認定ではなく， 診断や維持管理という総合的な技術領域を主眼としたも のとなっていることが特徴である. 行政においても，ア セットマネジメントや長寿命化への取り組みが本格化し ている1). また，先進的な機能を有するデータベースや マネジメントシステムの整備も進められている47),45).

このように，現代は，社会的関心の高まりを背景に， これまでの蓄積の上に新たな展開が模索されている段階 であると考えられる.

\section{3. 米国における維持管理の発展}

維持管理における検査や情報管理に関して先進的な取 り組みで知られ，また，関連した情報も豊富な米国交通 省（DOT: Department of Transportation）連邦道路局 (FHWA: Federal Highway Administration) の橋梁マネジメ ント ${ }^{34,460)}$ に焦点を当て，その発展の経緯を概観する.

\section{(1) 橋梁検査プログラムNBIPの発足}

FHWA では，1971 年から全米橋梁検査プログラム (NBIP: National Bridge Inspection Program) が実施されてい る. NBIPは，1967 年に死者 46 名を出したウェストバー ジニア州ポイント・プレザントにおけるシルバー橋の落 橋を契機に発足している47). シルバー橋は，アイバーを 用いた吊橋であったが，アイバーの応力腐食割れによっ
て橋が崩壊したものである.

この事故を受けて, FHWA は，2 年に一度連邦議会に 対して全国の橋梁の状態を報告する法的義務を負うこと となった，それ以前は，少なくとも連邦レベルで橋梁の 状態を把握する手段が存在していなかったが，NBIP に より，全米橋梁台帳（NBI: National Bridge Inventory）が整 備されるとともに，最低 2 年に一度の検査が義務付けら れたため, 情報の取得と集計が系統的に行われるように なった. 全米約 60 万橋に対してそれぞれ 119 項目から なるデータを取得し管理しており，1971 年から現在ま で 35 年間の蓄積を有している. 橋梁マネジメント上, 極めて有効な情報資源であると言える.

NBIP は，事故をきっかけにスタートしたことからも 伺えるように，欠陷橋を無くすことを主目的としたもの であり，検査結果は，連邦政府の道路橋更新・修繥プロ グラム ( HBRRP: Highway Bridge Replacement and Rehabilitation Program) において, 各州に予算を配分する ための基礎資料として用いられている.

このように，NBIPは，連邦政府レベルで全国の橋梁 の状態を把握するためのものである. 維持管理に関わる 技術的な観点というよりは，全国の社会資本のマネジメ ントという観点から開始されているところが興味深く, また，情報管理に重点があることが重要な特徴であると 言える. なお， NBIデータは，HP上でも公開されており， 州毎にどれぐらいの欠陷橋が存在するか，などを容易に 調べることができる ${ }^{48)}$.

\section{(2) 橋梁マネジメントから性能評価へ}

一方，実際に橋梁の維持管理にあたる州における道路 ネットワークレベルの橋梁群のマネジメントには, NBI データのみでは不十分であることが指摘されるようにな り, 1990 年代より, 州レベルの管理者のマネジメント 支援のためのデータ整備と検査手法が新たに開発され, 実施されるようになった。 それを，具体化したものがよ り詳細な部材レベルの検査と劣化予測を含むPONTIS と して知られる橋梁マネジメントソフトウェアである. そ れにより, 米国の橋梁マネジメントは, 第 2 世代に入っ たと考えられる. 検査の高度化と情報管理が同時に進展 していることが興味深い. 1983 年のマイアナス橋の落 橋年ををはじめとして，1980 年代に社会資本の荒廃が進ん だ50こともこのような展開の背景にあると考えられる.

さらに，2006会計年度より，20年間のプログラムとし て, 橋梁長期性能プログラム (LTBPP: Long Term Bridge Performance Program) が開始されている51).これは, これ までの検査が，目視による定性的な検査が主体で，必ず しも予測モデルの高度化に結びついていないことから， 全米で数千の橋を代表サンプル橋として選定し, 定量的 な計測を含む詳細な検査を実施して性能の変化を追尾す 


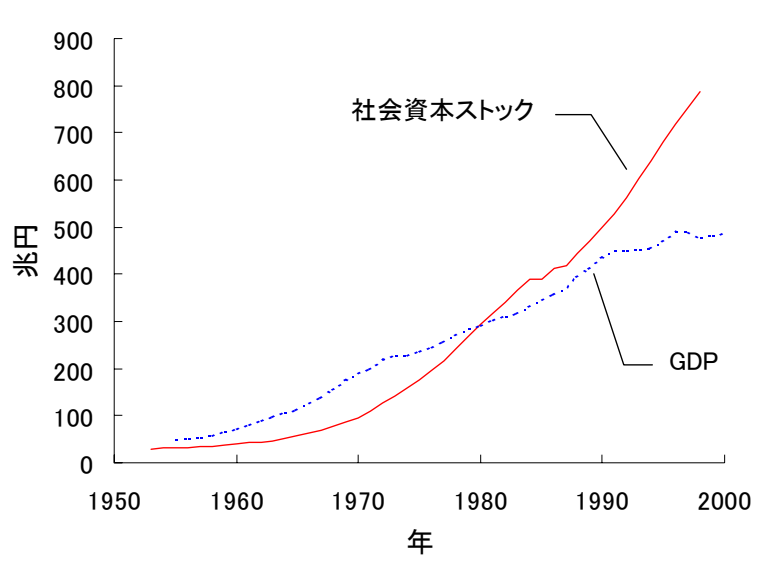

図-7 社会資本ストック ${ }^{52)}$ と実質 $\mathrm{GDP}^{53}$ の推移

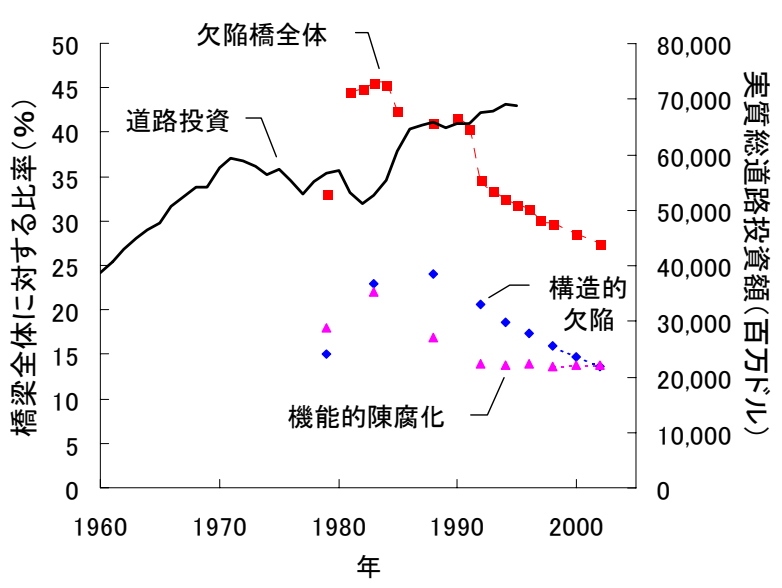

図-8 米国における橋梁欠陥率と道路投資の推移 (文献56)-59)上り作成)

あると考えられる．また，而震補強も，耐震基準の見直 しに伴う一種の陳腐化対応であるとも解釈できる.

現代は，膨大となったストックの劣化の懸念から，維 持管理に注目が集まっている時代であると考えられ，い

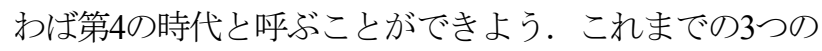
時代のどれとも様相が異なるが，劣化に投資が追いつか ないという点では，維持管理不足が大規模劣化を招いた 戦中期が近いものであると推測される. 戦中期のように 全く放置されている状態ではないから，その表れ方はよ り緩やかであると予想されるが，ストック量は，図-7に 示したとおり, 当時の比較にならないほど増加している. 一方，GDPの伸びは鈍化しているから，単位ストックに 必要とされる維持管理費用が一定であるとすると, ス卜 ックを維持するためにはGDPのより大きな割合が維持管 理に振り向けられざるを得ないことになる，そこで，維 持管理不足による経済成長への悪影響 ${ }^{54)}$ や，「成長の限 界」 ${ }^{55}$ が指摘しているような「投資が減耗に追いつかな くなり産業の基盤が崩壊」するという破局のシナリオに 類似した事態の発生が長期的に懸念されている. したが って，適正な資源の投入水準を明らかとして効率的な維 持管理を実施するとともに，革新的な長寿命化のための 技術の研究開発が強く求められていると考えられる.

\section{(2) 米国との比較}

米国では，検査によって得られた技術情報が集計され て議会に報告され，それが予算配分という社会的意思決 定に反映される仕組みが成立していることを指摘した. その結果, 図-8 に示したとおり, 近年の道路投資の増 大に伴って，着実に欠陷率が低下している．なお，ここ でいう「久陌橋」は，構造的欠陥あるいは機能的陳腐化 を有する橋であり, NBI で定義されている補修が必要な “deficient bridge”を指寸. 


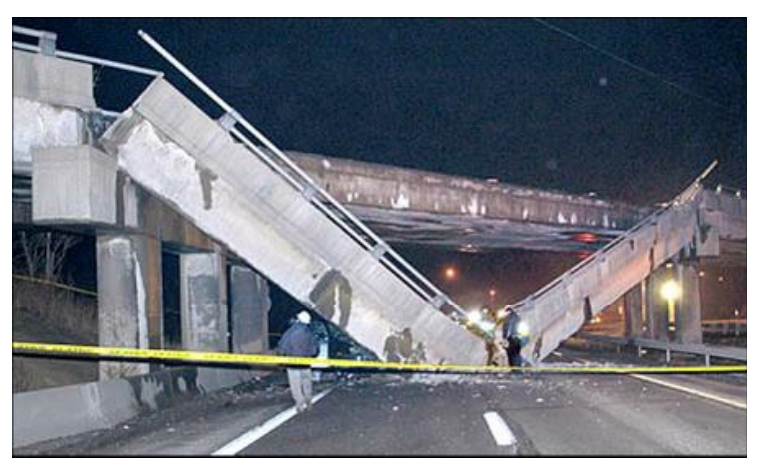

写真-2 2005 年 12 月 28 日の I-90架道橋の落橋事故 $\mathrm{PC}$ 鋼線の腐食により自重で崩壊したと考えられる. 2005 年 8 月に目視検查が実施されていた. Copyright, Pittsburgh Post-Gazette, 2005 , all rights reserved. Reprinted with permission.

一方，我国では，前述したように，橋梁マネジメント ソフトウェアやデータベースの整備が進展しており, 維 持管理に関する技術情報を意思決定に反映する基盤が確 立されつつあるが，米国の議会報告のような高度な社会 的意思決定にフィードバックする仕組みは明確には整っ ていない.

今後, 増大寸る老朽ストックへの維持管理ニーズに対 して，資源投入の正当性を評価し，合理的な資源配分と 実施を支援する，技術に基盤を有するマネジメントが求 められる. 米国の例では, NBIデー夕によって, 資源配 分については一定の合理性を持つ決定がなされていると 考えられるが，1980 年代には財源が不足して荒廃が進 むなど，全体の投入水準の合理性・正当性を説明するに は至っていないと考えられる. また, 最近でも, 写真-2 のようなPC橋の落橋 ${ }^{(0)}$ や，鋼林の破断61)などの事故が発 生している. それが，LTBPP発足の一つの背景ともなっ ている.

米国では事故を起点としたNBIPの発足が維持管理の 発展に大きな影響を与えた。 NBIPは，基本的に，予算 配分を合理的に行うためのプログラムであって, 維持管 理への適正な資源配分を通した社会資本のマネジメント という「社会的側面」が重視された施策であると考えら れる.「技術的側面」を重視したLTBPP発足が最近であ ることからもそれが伺える，この発展の経緯は，我国で 主流の個別の劣化予測を積み重称て全体像を把握寸ると いう積み上げ的アプローチの逆であるとも言え，今後の 我国の維持管理・マネジメントの方向を考える上で参考 となると思われる。

大局的に記述寸れば，米国では，マクロ的な視点で社 会的側面から施策が進められた面が強いが，我国では, ミクロ的な視点とも言える技術的側面からの発展が主流 である，その理由については，社会的背景を含めて各種
の要因が考えられるが，技術的には，我国においては， 当初，外国から高い技術がもたらされたことや，事故な どの社会的要請が発生する以前に，高い意識を持った技 術者の判断によって耐久性への検討が進められ, 結果と して米国のような大惨事が発生しなかったことなどが原 因として考えられよう.

\section{5. まとめ}

ここでは，橋梁を中心として我国における社会基盤の 維持管理技術の歴史を振り返り，また，米国での発展の 経緯との比較から, その特徵を論じた. 主たる結論は以 下のとおりである.

・我国では, 戦前より, 主に技術的観点から維持管理 の重要性が認識されており, 維持管理上の不具合の 設計へのフィードバックや，経済面を含めた検討が 行われている．また，鋼材が貴重であったことを背 景として, 各種補修工法の開発や再利用なども活発 に行われていた.

- 歴史的に，維持管理技術は，ストックのA.陳腐化， B.劣化，C.初期不良を背景として発展してきたこと を論じた。それぞれの課題は，Aについては大正時 代の機関車大型化に伴う橋梁の弱小化，Bでは戦時 中の維持管理不足, Cでは高度経済成長に伴う大量 整備, を背景として顕在化し, 維持管理に大きな影 響を与えている.

・米国では, 橋梁の事故を起点として, 連邦政府レベ ルで全米の橋梁の状態を把握する検査プログラムで あるNBIPが発足し，本格的な維持管理対策が実施さ れるようになった. 次いで, 橋梁群のマネジメント システムの構築が行われ, 現在は, 長期橋梁性能の モニタリングが進められている.

・国際的な比較では，米国では維持管理を社会的な側 面から資源配分の問題と捉える傾向が見られ，社会 資本マネジメントの観点が先行していると考えられ る. それに対して, 我国は, 技術的な問題意識を起 点として維持管理が発展してきた傾向がある.

- 日米ともに, 系統的な検査の実施と情報の管理が, 技術の発展に大きな影響を与えている.

現代は, 膨大となったストックの劣化の懸念から, 維 持管理に注目が集まっている時代であると考えられ，い わば「第 4 の時代」と位置付けられる. これまでの時代 に見られなかった，極めて大規模なストックの管理に対 応寸る革新的な技術が求められている時代であると考え ることができる.

なお, 本研究は, 橋梁を中心として歴史的視点ならび に日米の国際比較から，維持管理分野全体の俯瞰を試み 
たものであり, さらに客観的かつ深化された議論を進め るには，より幅広い社会基盤構造物ならびに多国間の分 析が求められる。 その意味では, 本研究の対象は限定的 ではあるが，発展的な分析のための基盤を与えるもので あると位置付けられよう。

謝辞：本報告をまとめるにあたり，FHWA・TurnerFairbank Highway Research CenterのSteven B. Chase氏には，米 国における橋梁検查・維持管理の現状およびLTBPPに関 してヒアリングに応じて頂いた. ここに記して謝意を表 する.

\section{参考文献}

1) 国土交通省 : 道路構造物の今後の管理・更新等のあり方提 言, 2003.

2) 多田宏行 : 橋梁技術の変遷, 鹿島出版会, 2000.

3) 日本国有鉄道: 鉄道技術発達史, 1958 .

4) 鉄道施設技術発達史編纂委員会: 鉄道施設技術発達史, 日 本鉄道施設協会, 1994.

5) 阿部允, 阿部雅人 : 橋梁のメンテナンス, 日本鉄道施設協 会誌, Vol.44,No.6, pp.2-5, 2006.

6) 中井祐 : 近代日本の橋梁デザイン思想一三人のエンジニア の生涯と仕事, 東京大学出版会, 2005.

7) 久保田敬一: 本邦鉄道橋梁ノ沿革二就テ, 業務研究資料, 鉄道大臣官房研究所, Vol.22,No.2, 1934.

8) 東憲昭 : 軌道構造と材料, 交通新聞社, 2001.

9) 枕木の平均寿命の算出の一法, 土木学会誌, Vol.1, No.2, pp.687-694, 1915.

10) 軌道の経済的敷設年限，土木学会誌，Vol.1，No.2，pp.694 699, 1915.

11) 高崎哲郎: 評伝 山に向かいて目を挙ぐ一工学博士・広井勇 の生涯，鹿島出版会，2003.

12) Bosworth, D.L.; The rate of obsolescence of technical knowledge - a note, The Journal of Industrial Economics, Vol.26, No.3, pp.273-279, 1978.

13) 梶川康男 : 鋼橋の大移動地図一既存ストックの有效活用の 実例一，JSSC，No.57，pp.1-11，2005.

14) 中原壽一郎, 大津寬, 飯田三郎 : 鈑林のトラストビーム式 補強法並びに其の効果に就いて, 業務研究資料, 鉄道大臣 官房研究所, Vol.17,No.2, pp.165-179, 1929.

15) 高坂紫朗 : 鉄道防災改良施工法，三報社，1955.

16) 西村俊夫 : 国鉄卜ラス橋総覧，鉄道技術研究資料，Vol.14, No.12, 1957.

17) 西村俊夫 : 溶接鉄道橋の破損事故, 溶接学会誌, Vol.37, No.10, pp.12-16, 1968.

18）西村俊夫, 三木千寿: 引張応力に起因寸る鋼橋梁の変状, 土木学会誌, Vol.60, No.12, pp.55-64, 1975.

19）西村俊夫, 大野正 : 餘部橋梁の実態と対策, 構造物設計資 料，No.5，pp.190-197，日本国有鉄道構造物設計事務所，1966

20) 友永和夫：鉄道橋の保守ならびに補強法について，昭和 26 年度土木学会夏期講習会テキス卜, 1951.

21) 日本国有鉄道施設局 : 建造物保守心得（案），1956.

22)小林一輔 : コンクリートが危ない, 岩波書店，1999.

23) 日本道路協会 : 道路維持修繥要綱, 1978.

24) 日本道路協会 : 道路橋補修便覧, 1979.

25) 建設省土木研究所 : 橋梁点検要領（案）, 土木研究所資料, No.2651, 1988.
26) 松井繁之編著 : 外ケーブルによる鋼橋の補強，森北出版， 2005.

27) 日本国有鉄道 : 建造物検查標準解説, 日本鉄道施設協会, 1966.

28) 日本国有鉄道施設局土木課 : 土木建造物取替の考え方，日 本鉄道施設協会, 1974 .

29) 日本国有鉄道鉄道技術研究所監修: 高速鉄道の研究一主と して東海道新幹線について一, 研友社, 1967.

30) 牧添親男：防災投資の基本的な考え方，鉄道土木，Vol.15, No.6,pp.79-81, 1973.

31) 鉄道総合技術研究所 : 建造物保守管理の標準・同解説（鋼 構造物），1987.

32) 鉄道総合技術研究所 : 建造物保守管理の標準・同解説 (コン クリート構造), 1987.

33) 村上温: 維持管理と施設寿命, 土木計画学シンポジウム, No.17, pp.30-36, 土木学会, 1983.

34) Yanev, B.: Bridge Management, John Wiley \& Sons, 2007.

35) 日本鋼構造協会 : 鋼構造物の疲労設計指針・同解説，技報 堂出版, 1993.

36) 土木学会 : コンクリート構造物の耐久性設計指針（試案）, コンクリートライブラリー, No.65, 1989.

37) 土木学会 : コンクリート構造物の維持管理指針（案），コ ンクリートライブラリー, No.81, 1995.

38) 土木学会 : 2001 年制定コンクリート標準示方書 [維持管理 編] , 2001.

39) 前田幸雄, 松井繁之 : 移動輪荷重走行装置による道路橋床 板の疲労に関する研究, 第 6 回コンクリート工学年次講演会 論文集, 1984 .

40) 新しい鋼橋の設計編集委員会 : 新しい鋼橋の設計, 山海堂, 2002.

41) 土木学会メインテナンス工学連合小委員会 : 社会基盤メイ ンテナンス工学, 東京大学出版会, 2004.

42) 日本コンクリート工学協会 : コンクリート診断技術’06, 2006.

43) 日本鋼構造協会 : 土木鋼構造物の点検 - 診断 - 対策技術, 2005.

44) 室井智文, 窪田賢司，紫桃孝一郎，稲葉尚文，横山和昭， 山根立行 : 橋梁マネジメントシステムにおける劣化度評価 手法に関する一考察，構造工学論文集，Vol.51，pp.1139-1146, 2005.

45) 道路管理データベースシステム MICHI，道路保全技術セン ター, http://www.hozen.or.jp/center/business/michi.html

46) 東京大学 21 世紀 COE プログラム「都市空間の持続再生学 の創出」 : 都市のストックデータのマネジメントと利用に 関するセミナー講演資料集, 2006 .

47) Weingroff, R.F. : A peaceful campaign of progress and reform: The Federal Highway Administration at 100, Public Roads, Vol.57, No.2, 1993.

48) Bridge Technology, Federal Highway Administration, U.S. Department of Transportation, http://www.fhwa.dot.gov/bridge/britab.htm

49) ダンカー, K.F., ラバット, B.G. : 米国の橋はなぜ落ちる, 日経サイエンス, Vol.23, No.5, pp.78-86, 1993.

50) 大石久和 : 荒廃したアメリカに学べ, 中央公論, 8 月号, pp.232-242, 2006.

51) Chase, S.B., Duwadi, S.R. and Hooks, J.M.: Getting ahead of the curve, Public Roads, Vol.67, No.3, 2003.

52) 内閣府政策統括官編：日本の社会資本, 財務省印刷局, 2002.

53) 内閣府経済社会 総合研究所国民経済計算部 : 長期時系列 （GDP・雇用者所得）（68SNA，平成 2 年基準），昭和 30 
年-平成 13 年 1-3 月期 : http://www.esri.cao.go.jp/jp/sna/ qe01168/gdemenuj68.html

54) Kalaitzidakis, P. and Sarantis Kalyvitis, S.: On the macroeconomic implications of maintenance in public capital, Journal of Public Economics, Vol.88, No.3-4,pp. 695-712, 2004.

55) D.H.メドウズ，D.L.メドウズ，J.ラーンダズ，W.W.ベアラン ズ 3 世（大来佐武郎監訳）：成長の限界，ダイヤモンド社， 1972.

56) 国土交通省 : 平成 14 年度国土交通白書，ぎょうせい，2002.

57) U.S. Department of Transportation: Status of the Nation's Highways, Bridges, and Transit: 2004 Conditions and Performance, Report to Congress, 2006.

58) U.S. Department of Transportation: 1999 Status of the Nation's Highways, Bridges, and Transit: Conditions and Performance Report, Report to Congress, 2000.
59) 米国連邦議会技術評価局編（建設経済研究所訳著）：社会 基盤の再建，開発問題研究所，1992.

60) Westbound I-70 reopens after overpass collapses, Pittsburgh Post-Gazette, December $28^{\text {th }}, 2005$.

61) Fischer, J.W., Kaufmann, E.J., Wright, W., Xi, Z., Tjian, H., Sivakumar, B. and Edberg, W.: Hoan Bridge Forensic Investigation Failure Analysis Final Report, Wisconsin Department of Transportation and the Federal Highway Administration, 2001.

(2006.9.4 受付)

\section{DEVELOPMENT AND CHARACTERISTICS OF INFRASTRUCTURE MAINTENANCE OF JAPAN WITH EMPHASIS ON BRIDGES}

\section{Masato ABE, Makoto ABE and Yozo FUJINO}

The paper presents characteristics and challenges of Japanese maintenance technology through investigation of historical development and comparison with U.S. It is shown that Japanese development is motivated by the status of infrastructure stock of each age, i.e., A) functional obsolescence at Taisho era, B) deterioration at WWII period, and C) initial defect at post war economic growth period. In comparison to U.S., Japanese development is more focused to technological aspects, while importance of resource allocation is stressed in U.S. from social point of view. In both countries, technological development is highly influenced by implementation of systematic inspection and information management 